\title{
Phytotechnologies to promote sustainable land use and improve food safety: outcomes and outlook from the European COST Action 859
}

\author{
Jean-Paul Schwitzguébel • Peter Schröder
}

Received: 13 July 2009 /Accepted: 8 September 2009/Published online: 18 September 2009

(C) Springer-Verlag 2009

\section{Background}

According to the United Nations Environment Program, "phytotechnologies are ecotechnologies relating to the use of vegetation, to resolve environmental problems in a watershed management, by prevention of landscape degradation, remediation and restoration of degraded ecosystems, control of environmental processes, and monitoring and assessment of environmental quality."

\section{Results}

Phytotechnologies are beginning to offer efficient tools and environmentally friendly solutions for:

- The cleanup of contaminated sites and water

- The improvement of food chain safety

- The development of renewable bioenergy

In short, phytotechnologies contribute to the sustainable use of water and land.

Responsible editors: Jean-Paul Schwitzguébel • Peter Schröder

J.-P. Schwitzguébel $(\bowtie)$

Laboratory for Environmental Biotechnology, EPFL,

Station 6,

1015 Lausanne, Switzerland

e-mail: jean-paul.schwitzguebel@epfl.ch

P. Schröder

Department Microbe-Plant Interactions,

Helmholtz Zentrum München,

Ingolstädter Landstraße 1,

85764 Neuherberg, Germany

e-mail: peter.schroeder@helmholtz-muenchen.de

\section{Discussion}

However, each of these goals requires a sound understanding of how plants can specifically accumulate or exclude essential elements, toxic metals, and organic pollutants.

Research is indispensable on the bioavailability of metals and xenobiotics in the rhizosphere, their uptake by roots, their translocation to and detoxification/ storage in the above-ground parts of the plant, and that at the physiological, the biochemical, and the molecular level.

\section{Conclusions}

In the European framework of COST Action 859 (http://w3.gre.ac.uk/cost859/), significant efforts have been carried out as to the integration and expansion of research and development in order to implement phytotechnologies as instruments for the removal and/or management of environmental pollutants. This network aimed to contribute to the implementation, assessment, and integration of efficient phytotreatments for sustainable land use management, ecosystem restoration, and mitigation strategies applicable to different environmental compartments.

Four topics were thus addressed by different working groups of COST Action 859:

(1) Plant uptake/exclusion and translocation of nutrients and contaminants

(2) Exploiting omics approaches in phytotechnologies

(3) Improving nutritional quality and safety of food crops

(4) Environmental pollution and potentials of phytoremediation 


\section{Outcomes}

The purpose of the thematic set of papers in this issue of Environmental Science and Pollution Research is:

- To present major outlines, outcomes, and perspectives emanated from the network

- To highlight significant progress in Europe over the last 5 years

- To identify some critical points in overcoming bottlenecks in plant removal and detoxification of pollutants

Two comprehensive reviews (Bert et al. 2009; Vangronsveld et al. 2009) present the current knowledge and recent developments in phytoremediation of contaminated sediments, soils, and groundwater.

Seven research articles address some more specific topics where significant results have recently been obtained:

- Interactions between trace elements and detoxification of organic pollutants (Schröder et al. 2009)

- Direct use of organic contaminants as substrates for cytochromes P450 monooxygenase (Page and Schwitzguébel 2009)

- Interactions of plants with rhizospheric and endophytic bacteria to degrade PCBs and chlorinated solvents (Mackova et al. 2009; Weyens et al. 2009)

- Metal uptake in relation to salinity (Manousaki and Kalogerakis 2009; Barazani and Golan-Goldhirsh 2009)

- Establishment of constructed wetlands under extreme conditions (Tencer et al. 2009)

Finally, successful experiments and limitations of phytotechnologies are assessed for contaminant uptake, detoxification, and sequestration, with consequences for food safety (Mench et al. 2009).

Over the last 5 years, COST 859 has demonstrated in which way plants can be used to accumulate toxic metals and organic pollutants from contaminated sites for cleanup purposes, in order to prevent further degradation of our environment and to remediate damage caused by our increasingly industrialized society.

It has also been shown that crops with a reduced capacity to accumulate toxic metals and organic pollutants in edible parts are valuable to improve food safety, and even more crop plants with an enhanced capacity to accumulate essential minerals can help to feed the world and improve human health through balanced mineral nutrition.

\section{Perspectives}

In the future, the use of plants specifically chosen or tailored for the rehabilitation of polluted lands and brown- fields, water purification, and even removal of indoor or outdoor air contaminants will become essential for a sustainable development. Green and environmentally compatible biotechnologies are less expensive methods of site restoration compared to physicochemical and engineering approaches, even though the time scale required to reach the fixed end-points can become a limiting factor. Plants are beneficial to human health, and they are already cleaning our environment constantly, everywhere, even if we do not recognize or know it.

\section{References}

Barazani O, Golan-Goldhirsh A (2009) Salt-driven interactions between Pistacia lentiscus and Salsola inermis. Environ Sci Pollut Res 16(7). doi:10.1007/s11356-009-0231-4

Bert V, Seuntjens P, Dejonghe W, Lacherez S, Thi HTT, Vandecasteele B (2009) Phytoremediation as a management option for contaminated sediments in tidal marshes, flood control areas and dredged sediment landfill sites. Environ Sci Pollut Res 16(7). doi:10.1007/s11356-009-0205-6

Mackova M, Prouzova P, Stursa P, Ryslava E, Uhlik O, Beranova K, Rezek J, Kurzawova V, Demnerova K, Macek T (2009) Phyto/ rhizoremediation studies using long-term PCB-contaminated soil. Environ Sci Pollut Res 16(7). doi:10.1007/s11356-0090240-3

Manousaki E, Kalogerakis N (2009) Phytoextraction of Pb and Cd by the Mediterranean saltbush (Atriplex halimus L.): metal uptake in relation to salinity. Environ Sci Pollut Res 16(7). doi:10.1007/ s11356-009-0224-3

Mench M, Schwitzguébel J-P, Schroeder P, Bert V, Gawronski S, Gupta S (2009) Assessment of successful experiments and limitations of phytotechnologies: contaminant uptake, detoxification and sequestration, and consequences for food safety. Environ Sci Pollut Res 16(7). doi:10.1997/s11356-009-252-z

Page V, Schwitzguébel J-P (2009) The role of cytochromes P450 and peroxidases in the detoxification of sulphonated anthraquinones by rhubarb and common sorrel plants cultivated under hydroponic conditions. Environ Sci Pollut Res 16(7). doi:10.1007/ s11356-009-0197-2

Schröder P, Lyubenova L, Huber C (2009) Do heavy metals and metalloids influence the detoxification of organic xenobiotics in plants? Environ Sci Pollut Res 16(7). doi:10.1007/s11356-0090168-7

Tencer Y, Idan G, Strom M, Nusinow U, Banet D, Cohen E, Schroeder P, Shelef O, Rachmilevitch S, Soares I, Gross A, Golan-Goldhirsh A (2009) Establishment of a constructed wetland in extreme dryland. Environ Sci Pollut Res 16(7). doi:10.1007/s11356-009-0232-3

Vangronsveld J, Herzig R, Weyens N, Boulet J, Adriaensen K, Ruttens A, Thewys T, Vassilev A, Meers E, Nehnevajova E, van der Lelie D, Mench M (2009) Phytoremediation of contaminated soils and groundwater: lessons from the field. Environ Sci Pollut Res 16 (7). doi:10.1007/s11356-009-0213-6

Weyens N, Taghavi S, Barac T, van der Lelie D, Boulet J, Artois T, Carleer R, Vangronsveld J (2009) Bacteria associated with oak and ash on a TCE-contaminated site: characterization of isolates with potential to avoid evapotranspiration of TCE. Environ Sci Pollut Res 16(7). doi:10.1007/s11356-009-0154-0 